ISBN 978-93-84422-85-1

11th International Conference on Chemical, Agricultural, Biological and Environmental Sciences

(CABES-2018)

April 17-18, 2018 Kyoto (Japan)

\title{
The Biomass Culture of Marine Phytoplankton Dunaliella Sp. in Arschat and Walne Medium by Compare Cells Concentration and Chlorophyl-a
}

\author{
Ito Purnomo ${ }^{1}$ and Arifin ${ }^{2}$ \\ ${ }^{1}$ Bandung Institute of Technology, West Java, Indonesia \\ ${ }^{2}$ Halu Oleo University, Southeast Sulawesi, Indonesia
}

\begin{abstract}
Microalgae are one of valuable alternate energy sources by biomass production. Microalgae can be extracted and converted to produce different types of biofuels such as biomethane; bioethanol; and biohydrogen. This study was focused on biomass production methods of marine microalgae Dunaliella sp. in Arshcat and Walne growth medium. This study uses experimental method with inorganic medium as an independent variable while cell concentration and chlorophyll-a content as dependent variables. Cell concentration and chlorophyll-a are measured by turbidimetry and spectrophotometry methods, respectively. The results showed that the cells concentration equal to pigment concentration. In Arschat medium, the growth period of Dunaliella sp. is shorter than in Walne medium. It was indicated that Arschat medium is enable to be used as a new methods for biomass culture for Dunaliella sp.
\end{abstract}

Keywords: Dunaliella sp., Arschat medium, Walne medium, chlorophyll-a, turbidimetry methods

\section{Introduction}

Microalgae are one of marine microorganisms that potential in developing of alternate energy for its ability to produce higher biodiesel than soybean oil[1]. In advantages, microalgae are capable of all year round production; therefore, oil productivity of microalgae cultures exceeds the yield of the best oilseed crops. Microalgae can be cultivated in brackish waters, therefore, the environmental impacts that occur can be minimized, while not compromising the production of food, fodder and other products derived from crops[2]. In the industry, microalgae have been used as source for a wide variety of practical and potential metabolic products, such as food supplements, pharmacological substances, lipids, enzymes, biomass, polymers, toxins, pigments, tertiary wastewater treatment, and green energy. Microalgae are also important in aquaculture as they are a source of nutrients and have great importance in production of oxygen, in consumption of carbon dioxide, and in consumption of nitrogen-based compounds such as ammonium[3].

The potentially microalgae that can be found in the waters of Indonesia is Dunaliella sp. The existence of this type plays an important role in the aquatic environment as the primary producer. This photosynthetic microalgae have chlorophyll to capture solar energy and carbon dioxide into organic carbon that is useful as a source of energy for life[4]. Dunaliella sp. contains chlorophyll-a and chlorophyll-b, carotenoids and

Xanthophyll including $\beta$-carotene, $\alpha$-carotene, cis- $\gamma$-carotene, lutein, 5.6-epoxid lutein, antheraxanthin, violaxanthin, zeaxanthin, and neoxanthin, but more prominent are lutein and $\beta$-carotene under proper inductive conditions[5][6]. Dunaliella sp. also known as the most halo tolerant eukaryotic organisms known, showing a remarkable degree of adaptation to a variety of salt concentrations from $0.2-35 \%$.

Although Dunaliella sp. is a unique microalgae, many challenges in the development of culture for sustainable production and utilization. Therefore, it will be important to find the best methods for cultivation, 
where environmental conditions are favorable for biomass production. One of the most effort to increase the production rate of microalgae is medium modification. In 2013, first introduced Arschat medium for biomass production of microalgae[7]. This medium use of sea water with the addition of several chemicals can provide maximum growth in a short period of microalgae. By considering that factors, Arschat medium is feasible to be tested on Dunaliella sp. The aims of this research are to investigate the effect of different medium to cell growth of Dunaliella sp. and to investigate the effect to chlorophyll-a content.

\section{Material and Methods}

\subsection{Dunaliella sp. cells}

Microalgae are grown in two mediums, where Walne medium used as check medium. All chemical reagents using were analytical grade and sterilized water. The preparation of Arschat medium are listed in table 1 and table 2. Walne medium composition are listed in table 3. The preparation of microalgae was cultured for 7 days. The culture condition as following $25-30 \mathrm{oC}$ of temperature, $30 \mathrm{ppt}$ of salinity and light intensity by using TL 40 watt. During cultivation, the physico-chemical parameters were maintained include salinity of the medium, $\mathrm{CO}_{2}$ gas from aeration, temperatures between $25-27 \mathrm{oC}$ and $\mathrm{pH}$ of seawater medium between 7.0-9.0. Cell density was calculated by Petroff-Hausser and turbidimetry methods. In Petroff-Hausser methods, determination of microalgae growth pattern was carried out by counting the number of cells per milliliter medium. Samples were dripped about $0.1-0.5 \mathrm{ml}$ on a haemocytometer, then observed through a microscope. Cell density of Dunaliella $s p$. measured daily. Sample measured by UV-Vis spectrophotometer at $680 \mathrm{~nm}$ of wavelength.

TABLE I: Macro Composition of Arschat Medium

\begin{tabular}{|c|c|c|c|c|c|c|c|}
\hline \multirow[b]{2}{*}{ No. } & \multirow[b]{2}{*}{ Reagent } & \multirow[b]{2}{*}{ Conc (mM) } & \multirow[b]{2}{*}{ MW } & \multirow[b]{2}{*}{$g / L$} & \multirow[b]{2}{*}{ Note } & \multicolumn{2}{|c|}{ Uses } \\
\hline & & & & & & Gram & $(\mathrm{ml} / \mathrm{L})$ \\
\hline 1. & $\mathrm{NaCl}$ & 400 & 58.45 & 23.38 & Direct addition & & \\
\hline 2. & $\mathrm{MgSO}_{4} \cdot 7 \mathrm{H}_{2} \mathrm{O}$ & 20 & 246.48 & 4.930 & Direct addition & & \\
\hline 3. & $\mathrm{KNO}_{3}$ & 3 & 101 & 0.303 & Stock $1 \mathrm{M} / 100 \mathrm{ml}$ & 10.1 & 3 \\
\hline 4. & $\mathrm{KH}_{2} \mathrm{PO}_{4}$ & 1 & 136 & 0.136 & Stock $1 \mathrm{M} / 100 \mathrm{ml}$ & 13.6 & 1 \\
\hline 5. & $\mathrm{CaCl}_{2} \cdot 2 \mathrm{H}_{2} \mathrm{O}$ & 10 & 110.99 & 1.110 & Stock $1 \mathrm{M} / 1000 \mathrm{ml}$ & 110.99 & 10 \\
\hline
\end{tabular}

Medium: Mixed (1, 2, 3, 4, and 5) in $775 \mathrm{ml}$ water

TABLE II: Micro Composition of Arschat Medium

\begin{tabular}{|c|c|c|c|c|c|c|c|c|c|}
\hline \multirow[b]{2}{*}{ No. } & \multirow[b]{2}{*}{ Reagent } & \multirow{2}{*}{$\begin{array}{l}\text { conc } \\
(\mu \mathrm{M})\end{array}$} & \multirow[b]{2}{*}{ MW } & \multirow{2}{*}{$\begin{array}{l}\text { Stock } 1 \\
(\mathrm{M} / \mathrm{ml})\end{array}$} & \multicolumn{2}{|c|}{ Uses } & \multirow{2}{*}{$\begin{array}{l}\text { Stock } 2 \\
(\mathrm{M} / \mathrm{ml})\end{array}$} & \multicolumn{2}{|c|}{ Uses (ml) } \\
\hline & & & & & Gram & $(\mathrm{ml} / \mathrm{L})$ & & $\begin{array}{l}\text { Stock } \\
1 *\end{array}$ & $\begin{array}{l}\text { Stock } \\
2^{+}\end{array}$ \\
\hline 1. & $\mathrm{H}_{3} \mathrm{BO}_{3}$ & 400 & 61.81 & $0.4 / 100$ & 2.4724 & 1 & $0.4 / 100$ & 1 & 1 \\
\hline 2. & $\mathrm{ZnSO}_{4} .7 \mathrm{H}_{2} \mathrm{O}$ & 2 & 191.37 & $0.2 / 100$ & 3.8274 & & $0.02 / 100$ & 1 & 1 \\
\hline 3. & $\mathrm{MnSO}_{4} 4 \mathrm{H}_{2} \mathrm{O}$ & 2 & 223.06 & $0.2 / 100$ & 4.4612 & & $0.01 / 100$ & & \\
\hline 4. & $\mathrm{CuSO}_{4} 5 \mathrm{H}_{2} \mathrm{O}$ & 0.1 & 249.50 & $0.01 / 100$ & 0.2495 & & $0.01 / 100$ & 1 & 1 \\
\hline 5. & $\mathrm{CoCl}_{2} 6 \mathrm{H}_{2} \mathrm{O}$ & 0.1 & 273.75 & $0.01 / 100$ & 0.2738 & & $0.01 / 100$ & 1 & 1 \\
\hline 6. & $\left(\mathrm{NH}_{4}\right)_{6} \mathrm{Mo}_{7} \mathrm{O}_{24} 4 \mathrm{H}_{2} \mathrm{O}$ & 0.1 & 1253.58 & $0.01 / 100$ & 0.9016 & & & & \\
\hline 7. & NaFeEDTA & 20 & 367.10 & $0.2 / 100$ & 7.342 & & & & \\
\hline 8. & $\mathrm{NaSiO}_{3} 9 \mathrm{H}_{2} \mathrm{O} * *$ & 100 & 259.09 & $0.1 / 100$ & 2.6909 & 1 & - & & \\
\hline \multirow[t]{3}{*}{9} & Tris mix (7.8) & \multicolumn{8}{|c|}{$0.023 \%=0.023$ Tris mix in $100 \mathrm{~g}$ water $(\rho$ water $=1 \mathrm{~g} / \mathrm{ml})$} \\
\hline & TRIS-HCl & & 157.6 & & 0.01722 & & & & \\
\hline & TRIS-base & & 121.4 & & 0.00778 & & & & \\
\hline 10. & Vitamin mix: & & & & & 1 & & & \\
\hline & $\begin{array}{l}\text { Biotin } \\
\text { Vit B1 } \\
\text { Vit B2 }\end{array}$ & & & 100 & $\begin{array}{l}0.2 \\
0.15 \\
0.2\end{array}$ & & & & \\
\hline
\end{tabular}

Note: $* 1 \mathrm{ml}$ stock 1 to make stock 2

***for diatom

${ }^{+} 1 \mathrm{ml}$ stock 2 to make $1 \mathrm{ml}$ medium 


\subsection{Measurement of Chlorophyll Content}

Measurement of chlorophyll content of Dunaliella sp. was performed by using HITACHI spectrophotometer type U-2900. Samples were taken $80 \mathrm{ml}$ then divided into 8 parts and centrifuged at $5000 \mathrm{rpm}$ for 5 minutes.

TABLE III: Composition of Walne Medium

\begin{tabular}{|c|c|}
\hline Composition & Walne (gram) \\
\hline \multicolumn{2}{|c|}{ Nutrient solution: } \\
\hline $\mathrm{NaH}_{2} \mathrm{PO}_{4} \cdot 2 \mathrm{H}_{2} \mathrm{O}$ & 20 \\
\hline $\mathrm{NaNO}_{3}$ & 100 \\
\hline $\mathrm{Na}_{2}$ EDTA & 5 \\
\hline $\mathrm{Na}_{2} \mathrm{SiO}_{3}$ & 40 \\
\hline $\mathrm{MnCl}_{2} \cdot \mathrm{H}_{2} \mathrm{O}$ & 0,36 \\
\hline $\mathrm{FeCl}_{3}$ & 1,3 \\
\hline $\mathrm{H}_{3} \mathrm{BO}_{3}$ & 10 \\
\hline Water & $1000 \mathrm{ml}$ \\
\hline \multicolumn{2}{|c|}{ Trace metal solution: } \\
\hline $\mathrm{ZnCl}_{2}$ & 21 \\
\hline $\mathrm{CoCl}_{2} \cdot 6 \mathrm{H}_{2} \mathrm{O}$ & 2 \\
\hline$\left(\mathrm{NH}_{4}\right)_{8} \cdot \mathrm{Mo}_{7} \mathrm{O}_{24} \cdot 4 \mathrm{H}_{2} \mathrm{O}$ & 0,9 \\
\hline $\mathrm{CuSO}_{4} \cdot 7 \mathrm{H}_{2} \mathrm{O}$ & 20 \\
\hline $\mathrm{FeCl}_{3} \cdot 6 \mathrm{H}_{2} \mathrm{O}$ & 3,15 \\
\hline Water & 100 \\
\hline \multicolumn{2}{|c|}{ Vitamin: } \\
\hline Vitamin B12 & 0,1 \\
\hline Thiamin & 20 \\
\hline Biotin & 0,1 \\
\hline
\end{tabular}

After the centrifuge process is complete, the supernatant is removed. The pellet then extracted with $1 \mathrm{ml}$ acetone $90 \%$ and $\mathrm{MgCO} 31 \%$. The samples were homogenized manually for approximately 5-10 minutes. The chlorophyll content is calculated refer to (1).

$$
\mathrm{K}=\frac{\mathrm{Ca} \times \mathrm{Va}}{\mathrm{V} \times \mathrm{d}}
$$

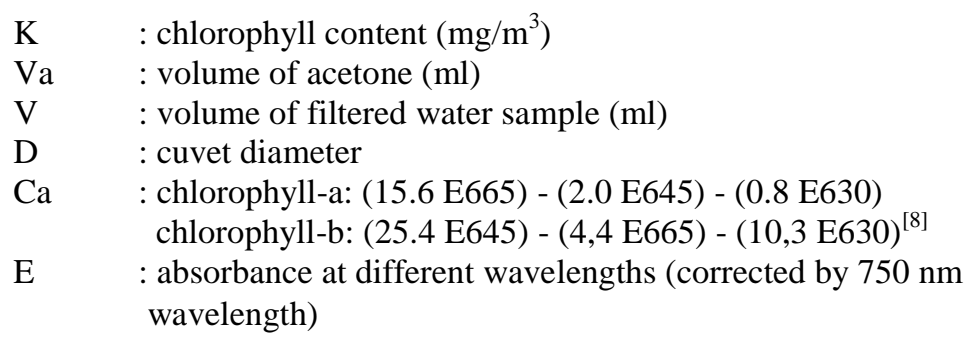

\section{Result and Discussion}

\subsection{Dunaliella sp. cells}

Measurement of microalgae by turbidimetry method is a fast and efficient indirect method of enumeration for estimating in liquid medium by measuring turbidity of culture ${ }^{[9]}$. The growth curve was showed the relation of the cells and absorbance that deviated linearly with cell concentration. In unicellular organism, optical density value (OD) is linear with population of the cell as a represent of the cell concentration. When the result showed that the value of transmitted light decrease, then the cell population of microorganisms in the solution were increased. To estimate the growth of microorganism culture, OD value should be correlated with result of direct counting by standard curve. The procedure was carried out by determine the turbidity of microorganisms in specific medium and then visualizing that turbidity by direct counting to find out amount of organism. Meanwhile, the disadvantages of this method is not selective for dead cells. 


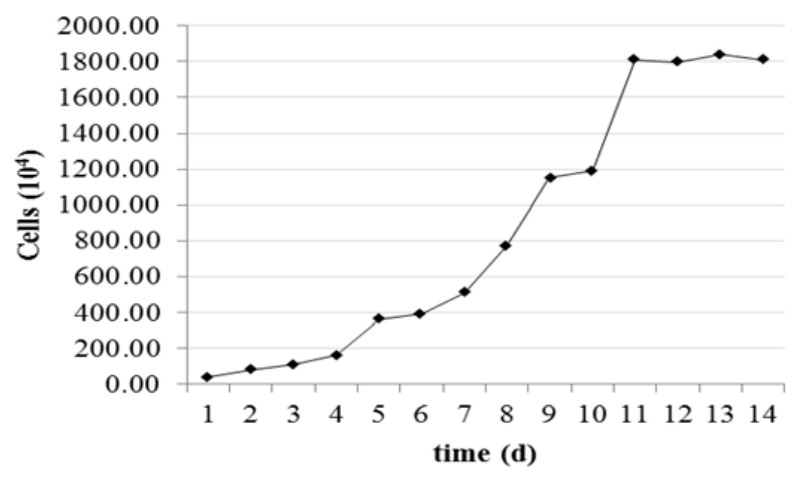

Fig. 1: Cells Concentration of Dunaliella sp. in Arschat medium

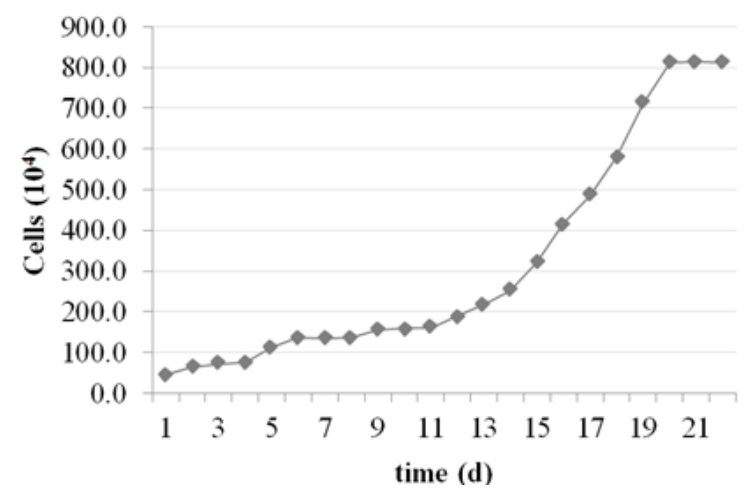

Fig. 2: Cells Concentration of Dunaliella sp. In Walne medium

Standard curve aims to estimate amount of cell by determine the turbidity value. Direct counting was carried out by calculation of microalgae use Petroff-Hausser methods or haemocytometer. Initial cells concentration of both medium were calculated on 7th days. The result of DO correlated with standard curve as showed in fig. 1 and fig. 2.

In Arschat medium, Dunaliella sp. has a quick growth since first day measurement. A lag phase was go on for 4 days, log phase on 5th to 11th days and then entering stationary phase. In Walne medium, cell growth of Dunaliella sp. tend to be slow. This caused by the cells of Dunaliella sp. were adapting to new condition. During that adaption, the cells are very active in metabolic activity but only few do accretion.

\subsection{Chlorophyll Content of Dunaliella sp.}

The microalgae abundance could be indicated profuse habitat. By observing chlorophyll content, the abundance of microalgae could be measured. Water fertility was influenced by plankton, chemical factor, physics and also chlorophyll-a. The content of photosynthetic pigments (especially chlorophyll-a) in the sample water describes the biomass of microalgae in a water. Therefore, to estimate the abundance of living cells of Dunaliella sp. in medium, the parameters used are chlorophyll-a. The result of chlorophyll-a content of Dunaliella sp. in both medium showed in fig. 3 and fig. 4. 


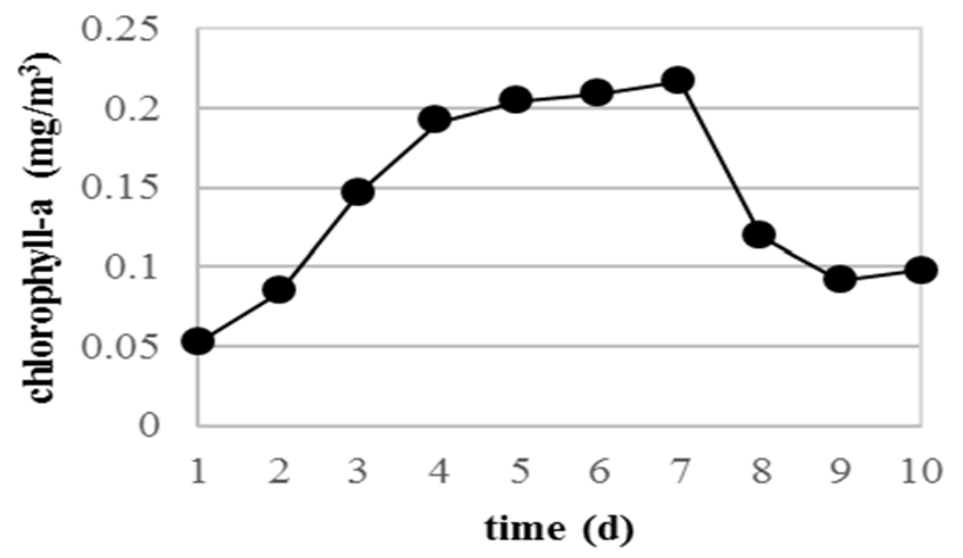

Fig. 3: Chlorophyll-A Content of Dunaliella sp. in Arschat Medium

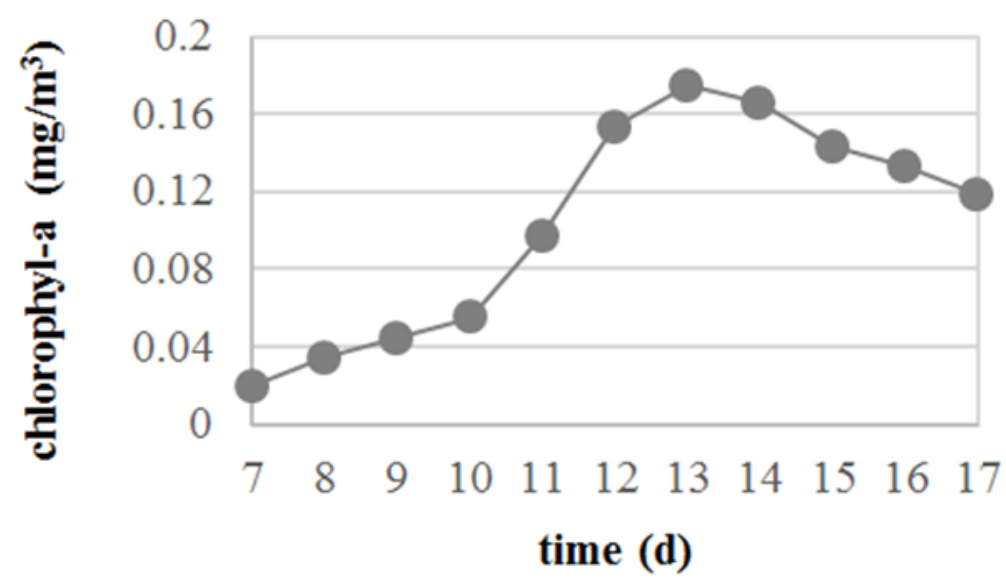

Fig. 4: chlorophyll-a content of Dunaliella sp. in Walne medium

The process of photosynthesis requires energy that obtained from the absorption of light by photosynthetic pigments. Light absorbing pigments at Dunaliella sp. are chlorophyll-a and other pigments such as carotenoids and xanthophyll. Chlorophyll-a is the only pigment that can distribute the light energy they absorb to photosynthesis, while other pigments simply transfer the light energy absorbed into chlorophyll-a[10]. Therefore, it is generally believed that chlorophyll-a is a pigment involved directly in the process of transforming light energy into chemical energy [11]. Chlorophyll-a concentration can be used as a measure of microalgae biomass. while the abundance of microalgae is related to the natural cycle of nutrient availability and nitrate and phosphate input. therefore, the content of chlorophyll-a microalgae can be used as an indicator of the low level of productivity of a waters[12].

Based on the results, chlorophyll-a of Dunaliella sp. in the Arschat medium and Walne medium were obtained the highest level of $0.217 \mathrm{mg} / \mathrm{m}^{3}$, in 7 th days and $0.175 \mathrm{mg} / \mathrm{m} 3$ in $13 \mathrm{rd}$ days, respectively. These results indicate that there are significant differences in chlorophyll content of Walne and Arschat mediums. Chlorophyll-a content in Arschat medium get the higher value than chlorophyll-a content in Walne medium was probably caused by direct addition of $\mathrm{MgSO}_{4} \cdot 7 \mathrm{H}_{2} \mathrm{O}$ in Arschat medium. Magnesium $(\mathrm{Mg})$ is the only metal element that is a component of chlorophyll. While on medium Walne there is no direct addition of magnesium element.

Phosphate and nitrate serve as a limiting factor for the growth of microalgae. In Walne medium, nitrate and phosphate content is $100 \mathrm{mg} / \mathrm{l}$ and $20 \mathrm{mg} / \mathrm{l}$. while the nitrate and phospate requirements for microalgae optimum growth are 0.9 to $3.5 \mathrm{mg} / \mathrm{l}$ and $0.09-1.80 \mathrm{mg} / \mathrm{l}$, respectively. These values were exceeds the threshold value of the phosphate and nitrate requirement for the growth. Therefore, microalgae were take longer to make adaptation 
in the medium. Phosphates affect the spread of microalgae especially diatoms. In Arschat medium, the value of nitrate and phosphate in Arschat medium is closer to the value of the optimum requirement for microalgae growth compared to the Walne medium. this may be the reason the medium Arschat gives better results

\section{Acknowledgements}

The author wishes to thanks to Indonesia Endowment Fund for Education (LPDP-RI) for financial support. The authors would also like to thank to La Rudi (head of Halu Oleo analytical laboratory) for providing guidance and encouragement during this study.

\section{References}

[1] Prartono, T., Kawaroe, M., Sari, D. W., \& Augustine, D. "Fatty Acid Content of Indonesian Aquatic Microalgae. HAYATI Journal of Biosciences, 2010, 17.4: 196-200.

https://doi.org/10.4308/hjb.17.4.196

[2] BRENNAN, Liam; OWENDE, Philip. Biofuels from microalgae - a review of technologies for production, processing, and extractions of biofuels and co-products. Renewable and sustainable energy reviews, 2010, 14.2: 557-577. https://doi.org/10.1016/j.rser.2009.10.009

[3] Araujo, G. S., Matos, L. J., Gonçalves, L. R., Fernandes, F. A., \& Farias, W. R. Bioprospecting for oil producing microalgal strains: evaluation of oil and biomass production for ten microalgal strains. Bioresource technology, 2011, 102.8: 5248-5250.

https://doi.org/10.1016/j.biortech.2011.01.089

[4] PRASOJO, ROMI. Utilization of Chicken Disposal Using Differentiation Effective Microorganism 4 Against for Growing of Population Dunaliella salina. 2012. PhD Thesis. Airlangga University. [in bahasa]

[5] Borowitzka, Michael A., and Lesley J. Borowitzka. Micro-algal biotechnology. Cambridge University Press, 1988.

[6] Celekli, Abuzer, and Gönül Dönmez. "Effect of pH, light intensity, salt and nitrogen concentrations on growth and $\beta$ carotene accumulation by a new isolate of Dunaliella sp." World Journal of Microbiology and Biotechnology, 2006, 22.2: 183 .

[7] Kasim, Syahruddin, and Hanapi Usman. "Utilization of Arschat Medium on Biomass Production of Microalgae Potential as Raw Material Types of Bioethanol.” Prosiding Seminar Nasional MIPA. 2013. [in bahasa]

[8] Richards, F. M., and T. E. Thompson. "Application of Mohr-Westphal balance to rapid calibration of wide range density-gradient columns." Analytical Chemistry, 1952, 24.6: 1052-1053.

https://doi.org/10.1021/ac60066a049

[9] Madigan, M. T., Martinko, J. M., Stahl, D. A., \& Clark, D. P. Archaea. Brock biology of microorganisms, 13th edn. Pearson Benjamin Cummings, San Francisco, 2012, 556-583.

[10] Dring, M. J. "Light harvesting and pigment composition in marine microalgae and macroalgae." Light and Life in the Sea, 1990, 89-103.

[11] Curtis, H. Biology. Second Edition. Worth Publisher, Inc. New York, 1978

[12] Ardiwijaya, Ricke Rizkiani. Horizontal Distribution of Chlorophyll-a and Its Relation with Nutrient and the Abundance of Microalgae in Semangka Bay, Lampung. Diss. IPB (Bogor Agricultural University), 2002. 